\title{
REARING CONDITIONS, HEALTH AND WELFARE OF DAIRY COWS**
}

\author{
S. Hristov*, B. Stanković ${ }^{1}$, Z. Zlatanović ${ }^{2}$, M. Joksimović Todorović \\ ${ }^{1}$, V. Davidović ${ }^{1}$ \\ 1 Faculty of Agriculture, Zemun \\ 2 JVS Niš \\ * Corresponding author: \\ Slavča Hristov, e-mail: hristovs@,agrifaculty.bg.ac.yu \\ ** Original scientific paper, presented at $2^{\text {nd }}$ International Congress on Animal Husbandry " New \\ Perspectives and Challenges of Sustainable Livestock Farming", Belgrade, 3.-5. October, 2007, \\ financed by Project BTN 351010B Ministry of Science and environment protection of Republic \\ of Serbia
}

\begin{abstract}
This paper provides an overview of recent developments in rearing conditions, health and welfare issues of dairy cows. The last approximately 30 years has witnessed worldwide increasing scientific research, consumer activity, and political response towards housing condition, health and welfare issues of dairy cattle. All buildings and housing systems for dairy cattle should be designed, constructed, maintained and managed to assist in the achievement of the Five Freedoms: freedom from hunger and thirst, freedom from discomfort, freedom from pain, injury and disease, freedom to express normal behaviour and freedom from fear and distress. Whether dairy cows are housed in cubicles, straw yards or cow sheds, in order to maximize their performance and to ensure satisfactory standards of welfare, the accommodation must provide the most basic behavioral and physiological needs. As an absolute minimum, the housing must provide a comfortable, clean, well drained and dry lying area together with shelter from adverse weather. Also, it must allow the cow to move freely around without risk of injury and certain diseases. If the housing system does not provide for these basic needs, then not only will health, welfare and production of dairy cattle be compromised, but it is likely that failure to comply with the welfare codes and the law relating to animal welfare will occur.
\end{abstract}

\section{Introduction}

The last 30 years has witnessed worldwide increasing scientific research, consumer activity, and political response towards housing condition, animal health and welfare issues. This is the case particularly in EU and other 
developed countries in the world. Also, there is major public demand for improvements in animal welfare, housing conditions and health aspects in developing countries. This demand is reflected in the activities of various lobbying organizations, through the media and ultimately at policy level, in the course of improved legislation. Although the driving force is public opinion, legislators have been careful to obtain scientific advices on housing condition, animal health and welfare issues and to take action within the scope of those advices. This paper provides an overview of recent developments in rearing conditions, health and welfare issues of dairy cows.

\section{Housing for dairy cow}

The most important aspects concerning housing condition designed for dairy cows are given in Animal Hygiene by Hristov (2002). Different aspects considering housing, welfare and behaviour of farm animals are reviewed by Hristov et al., (2006), microclimate and hygienic aspects by Hristov et al., (2006), effects of stress and especially thermal stress on dairy cow production by Hristov and Bešlin (1990) and Hristov et al., (2007), respectively. Also new standards concerning rearing conditions of domestic animals are described (Hristov, 2003), as well as effects of dust on animal organisms (Hristov et al., 1996). Data regarding production and behaviour of dairy cattle in different housing systems can be found in thesis (Fregonesi, 1999).

Because natural conditions in the most of world climate regions, seldom maintain cattle within their comfort zones throughout all seasons of the year, shelters are usually necessary to protect animals from inclement weather conditions. Appropriate confinement facilities protect both the animals and animal attendants from temperature extremes and potentially hazardous conditions. To accomplish this, all animal holding units should provide management and ease of handling during all times, including feeding, milking, breeding, parturition and health protection activities. Any confinement facility must be constructed and operated to meet the legal requirements for protection of product quality and to ensure that animals are always treated humanely (Leaver, 1999; Hristov, 2002).

The modern dairy cow is now significantly larger than the animals which were milked 30-40 years ago when much of the existing stables were constructed. If cows are kept for a considerable period of their lactation, inadequacy in housing systems become more obvious, creating significant adverse effects on health, welfare and production. The problem is multiplied by an increase in herd size without due account of the need to increase the housing facilities. Climate change will also have an impact on dairy stables, which need to be designed, built and managed to take account of the changing requirements 
of the dairy cow and the changing climatic conditions (Hristov, 2002, Hristov et al., 2006; Hristov et al., 2007).

All buildings and housing systems should be designed, constructed, maintained and managed to assist in the achievement of the Five Freedoms. The Five Freedoms which form a logical basis for assessing animal welfare $(F A W C$, 1993; DEFRA, 2003; Webster, 2005) within a husbandry system are: freedom from hunger and thirst, freedom from discomfort, freedom from pain, injury and disease, freedom to express normal behaviour, and freedom from fear and distress.

Whether cows are housed in cubicles, straw yards or cow sheds, in order to maximize their performance and to ensure satisfactory standards of welfare, the accommodation must provide the most basic needs. As an absolute minimum, the housing must provide a comfortable, clean, well drained and dry lying area together with shelter from bad weather. Also, it must allow the animal to move freely around without risk of injury and certain diseases. If the housing system does not provide for these basic needs, then not only will health, welfare and production of dairy cattle be compromised, but it is likely that failure to comply with the welfare codes and the law relating to animal welfare will occur (FAWC, 1993; DEFRA, 2003; Webster, 2005).

Housed dairy cattle need constant care and attention from staff that are well trained in the behavioral, nutritional and environmental needs of the cattle. No matter how long stock-keepers house the cows, their accommodation should give them shelter and enough room to move around and interact with each other. The accommodation should provide enough space for a subordinate cow to move away from a dominant one. It is important to provide as comfortable an area as possible, so that the animals can lie down for as long as they want and have enough space to stand up again. The floor should not slope too steeply no more than about $10 \%$ - as steeper slopes can cause leg problems, slipping and falling (Hristov, 2002; FAWC, 1993; DEFRA, 2003).

Ideally, for dairy herds stock-keepers should completely clean out straw yards every four to six weeks that the cows do not get too dirty and to reduce the risk of mastitis. If stock-keepers use straw yards, they should top them up with clean, dry straw every day. In the case of suckler herds, the frequency of cleaning out and topping up can be reduced. Stock-keepers should make sure that there is enough clean and dry straw available for as long as the animals are housed. Where possible, they should store this straw under cover to keep it dry. There should be enough space for all the animals to lie in comfort at the same time, or to stand up and move freely. Where feed and water troughs are provided in the adjacent loafing area, the access areas should be sufficiently wide to permit free movement of animals and prevent routes becoming wet, 
fouled and slippery. Where a loafing area is used it ought to, ideally, they should be partly covered. Stock-keepers will need to control the build-up of slurry in passageways and loafing areas by scraping them at least twice a day (Hristov, 2002; DEFRA, 2003).

Stock-keepers need to consider the size, shape and weight of the animals when they design the cubicles. Cubicle passageways should be wide enough for dairy cows to pass one another easily. Cubicles should be designed to encourage cows to lie down and stand up easily without injuring themselves. There is need to have enough bedding to keep the cows comfortable; prevent them from getting contact or pressure sores; and keep the cows' teats, udders and flanks clean. About $5 \%$ more cubicles than the number of dairy cows in the management group is recommended (DEFRA, 2003).

In cowsheds, the lying area should be big enough to help keep the cows clean and comfortable and to avoid them damaging their joints. Stock-keepers need to untie tethered cows and let them exercise at least once a day and give them feed and water if it is a long exercise period. The animals should also be able to groom themselves when tethered. The cowshed needs to be well ventilated. The internal surfaces of housing and pens should be made of materials that stock-keepers can clean and disinfect and easily replace when necessary (DEFRA, 2003).

Air circulation, dust levels, temperature, relative humidity and gas concentrations shall be kept within limits which are not harmful to the animals. All new buildings should be designed with the animals' comfort in mind, and with the aim of preventing respiratory diseases. The buildings should provide enough ventilation throughout the year for the type, size and number of stock to be housed in them. Where appropriate, roofs should be insulated to reduce solar penetration. Where the ventilation in existing buildings is not good enough, stock-keepers should adapt these buildings by improving air inlets and outlets, or by using mechanical equipment (Hristov and Relić, 2001; Hristov, 2002; Vučinić, 2006).

\section{Health and welfare of dairy cow}

Farm animal welfare is an increasingly important consideration for consumers, farmers, the veterinary profession and government, as a criterion for ensuring acceptable standards and conditions of food production. There are many definitions of animal welfare. The most generally accepted single definition of animal welfare is one from Fraser and Broom (1990). The welfare of an animal has been defined as its state at it seeks to cope with its environment. 
Different animal health topics in dairy farming are discussed in many articles. Most of them scrutinize many health problems in the dairy farming (i.e. Wells et al., 1998), especially lameness (Hughes, 1997, Logue et al., 1998; Ward, 2001) and mastitis (Edmondson and Blowey, 2001; Hristov, 1996; Hristov et al., 1997; Hristov et al., 1998; Logue, 2004, 2004a, 2004b).

It is well known the health is an important component of dairy cow welfare. The incidence and duration of an illness considerable affects the health of the animal (Webster, 2005; Vučinić, 2006). However, in terms of animal welfare, the intensity of pain and discomfort suffered from that disease are important. Diseases can affect an equal number of animals but can have quite different effects on the welfare of the animal. Behavior, welfare and productivity of dairy cattle are given by Rushen and Passille (1998), and behavior, performance and health indicators of welfare for dairy cows housed in straw yard or cubicle systems by Fregonesi and Leaver (2001).

Nowadays is well known that absence of disease does not necessarily suggest optimal animal welfare. However, the presence of disease usually indicates possible poor welfare issues (Webster, 2005; Vučinić, 2006).

There is a growing interest and concern about the welfare of housed dairy cattle. Over the past 50 years as herd sizes have increased, cowshed housing, in which cows are tied by the neck for extended periods during the winter months, has been replaced by straw yards and cubicles (Leaver, 1999). Although the knowledge base on animal welfare standards is developing, it is still difficult to objectively measure key physiological parameters that indicate the welfare status of farm animals; this can only be progressed by the conduct of fundamental and applied science (Webster, 2005).

If scan through the Five Freedoms can be used to identify systemic welfare problems for dairy cows, then:

- The cows may both suffer and fail to sustain fitness through hunger, malnutrition or metabolic disease if they are unable to consume or digest sufficient nutrients to support their genetic and physiological potential to produce milk.

- The cows may experience chronic discomfort if housing design, especially the design of their lying area, is inappropriate to their sizes and shapes. Problems of poor cubicle design and inadequate bedding may become worse if cows loss condition through malnutrition.

- The cows may suffer pain in the course of lameness or mastitis.

- The cow may show an increased susceptibility to infectious disease as a consequence of metabolic stress.

- Individual cow may be bullied or denied proper rest by other cows. 
- The cows may experience metabolic or physical exhaustion caused by the stress of extended high production. As well as its ethical importance, good welfare has been repeatedly demonstrated to have a beneficial effect on different aspects of dairy cattle production.

Maintenance of good health is the most basic requirement affecting the welfare of dairy cattle. Measures to protect health of dairy cattle include good hygiene, good husbandry and effective ventilation (Fregonesi and Leaver, 2001; DEFRA, 2003).

The written health and welfare plan should, as a minimum, look at: biosecurity arrangements on-farm and in transport; purchased stock procedures; any specific disease programmes, such as leptospirosis, John's disease, salmonellosis, BVD and tuberculosis; vaccination policy and timing; isolation procedures; external and internal parasite control; lungworm control; lameness monitoring and foot care; routine procedures, such as ear tagging; mastitis control. The health and welfare plan should make sure that animals get any necessary medical treatment at the correct time and in the correct dose. In geographical areas with known mineral deficiencies and imbalances - and where vitamin or mineral deficiencies are likely - there is need to supplement the animals' diet. (DEFRA, 2003).

Improvements in genetics of the dairy cow population have dramatically increased their milk yield over the last decade. However, increases in milk production have, to an extent, been at the expense of the health and well-being of cows, corresponding with an increase in production and metabolic diseases, decreases in fertility and culminating in the culling of cows at a younger age. The causes of some of these detrimental effects are attributed to a syndrome referred to as metabolic stress, which is considered to be prevalent in modern, high-yielding dairy cows. Metabolic stress is a recent concept; it generally refers to an imbalance in nutrient intake and demand, where cows have been genetically bred to maximize the conversion of nutrients to milk, decreasing the availability of nutrients for other biological functions such as maintenance of body weight, reproductive efficiency and health (Webster, 2005).

Lameness certainly stands out as a consequential and complex welfare problem in dairy cattle. The complexity arises because lameness is an obvious sign of many clinical, environmental and management problems (Hughes, 1997, Logue et al., 1998; Ward, 2001). Many factors influence hoof health including genetics, conformation, diet, contagious agents, hygiene, housing system, animal behavior and management (Bergesten, 2001). A key issue in the problem of lameness has been our inability to detect during its early stage. Recent research by Rajkondawar et al. (2001) indicates that it may be possible to use engineering tools to identify lameness in the cow in its very early stages where 
it is still easily treatable with a high probability of success. Continued research along these lines will assist dairy producers in their constant fight against the serious welfare problem of lameness. (Galindo and Broom, 2000).

Lameness is indisputably the major welfare problem for the dairy cow. It is estimated that half the cows go lame in any one year and $20 \%$ are lame at any one time (Webster, 2005). Lameness in any cow is usually a sign that they are in pain, ill-health and discomfort. It clearly affects cow welfare, as well as their performance and production. For this reason, very lame cows should be taken off concrete and housed in a suitably bedded pen. If a significant percentage of dairy cattle have severe lameness, this can be a sign of poor overall welfare standards within the herd (Hughes, 1997, Logue et al., 1998; Bergsten, 2001; Ward, 2001, DEFRA, 2003).

Dehorning of young calves was common practice worldwide. Nonmechanical means of ridding cattle of horns, such as genetic selection for polled dairy cattle has received little attention from the dairy industry. Since we continue the practice of dehorning, current research has focused on developing analgesic agents for dehorning calves including non-steroidal anti-inflammatory drugs such as ketoprofen (Faulkner and Weary, 2000).

There has been considerable research undertaken which confirms that dairy cows housed on a straw yard system will typically suffer elevated levels of clinical and especially subclinical mastitis over their counterparts housed in cubicles. Most important aspect about different mastitis are given in many papers (Edmondson and Blowey, 2001; Hristov, 1996; Hristov et al., 1997; Hristov et al., 1998; Hristov et al., 2000; Hristov et al., 2002; Hristov et al., 2005; Logue, 2004, 2004a, 2004b). If a herd has a serious problem with mastitis, there is need advice from a veterinary surgeon about introducing a suitable control programme. As with any other infection, mastitis can cause the animals distress and suffering so stock-keepers should therefore control it.

While cows are housed, the housing system must provide a comfortable lying surface. Cows at pasture will choose to lie down for approximately 11 hours every day and it is necessary to obtain similar lying time when cattle are housed. As a general rule, cows will lie for roughly 60 minutes only, after that time they become uncomfortable due to high pressure points on the parts of their body in contact with the surface. Close observation of cows shows that they will lie down and get up at least 10 times per day. If the cow spends less time lying down, she is likely to spend more time standing in loafing areas or at the feed stance which can adversely affect foot health. Maximizing lying times should be a clear objective with any cow housing system (Vučinić, 2006). 


\title{
Conclusion
}

On the basis of literature data and experience of authors about housing conditions, health and welfare of dairy cows it could be concluded that:

- There is worldwide increasing scientific research, consumer activity, and political response towards housing condition, animal health and welfare issues.

- All buildings and housing systems should be designed, constructed, maintained and managed to assist in the achievement of the Five Freedoms: freedom from hunger and thirst, freedom from discomfort, freedom from pain, injury and disease, freedom to express normal behaviour and freedom from fear and distress.

- Nowadays is well known that absence of disease does not necessarily suggest optimal animal welfare. However, the presence of disease usually indicates possible poor welfare issues.

- As well as its ethical importance, good welfare has been repeatedly demonstrated to have a beneficial effect on different aspects of dairy cattle production.

\section{Uslovi držanja, zdravlje i dobrobit muznih krava}

\author{
S. Hristov, B. Stanković, Z. Zlatanović, M. Joksimović Todorović, V.
} Davidović

\section{Rezime}

Ovaj rad daje pregled dosadašnjeg napretka po pitanju uslova smeštaja, zdravlja i dobrobiti mlečnih goveda. Poslednjih 30 godina je došlo do povećanja obima straživanja, aktivnosti kupaca uz politički odgovor kada su u pitanju uslovi smeštaja, zdravlja životinja i dobrobiti.. Svi objekti i sistemi za smeštaj moraju biti projektovani, izgrađeni i održavani da omoguće postizanje pet sloboda, koje predstavljaju logičnu osnovu ostvarenja dobrobiti životinja unutar sistema držanja čine: sloboda od gladi i žeđi, sloboda od neudobnosti, sloboda od bola, povreda i bolesti, sloboda ispoljavanja normalnog ponašanja i sloboda od straha i uznemiravanja. Bilo da se krave nalaze u boksovima, ležištima sa slamom (duboka prostirka) ili pod nastrešnicama, u cilju ispoljavanja maksimuma u proizvodnji i postizanja standarda dobrobiti, smeštaj mora zadovoljiti najosnovnije potrebe krava. Kao apsolutni minimum, smeštajem se mora obezbediti udoban, čist, ocedit i suv prostor za ležanje sa skloništem od lošeg vremena. Pored toga, mora svakoj životinji biti omogućeno da se slobodno 
kreće, bez rizika od povrede i određenih bolesti. Ako sistem držanja ne obezbeđuje ove osnovne potrebe, ne samo da će zdravlje, dobrobit i proizvodnja biti ugroženi, već će i zakonski propisi u pogledu dobrobiti ostati neispunjeni.

\section{References}

BERGSTEN, C. (2001): Effects of conformation and management system on hoof and leg diseases and lameness in dairy cows. Veterinary Clinics of North America: Food Animal Practice, 17: 1-23.

DEFRA (Department of the Environment, Food, and Rural Affairs). (2003): Code of Recommendations for the Welfare of Livestock: Cattle. HMSO, London.

EDMONDSON, P. and BLOWEY, R. (2001): The veterinary guide to mastitis. Intervet, UK.

FARM ANIMAL WELFARE COUNCIL (FAWC), (1993): Second Report on Priorities for Research and Development in Farm Animal Welfare. DEFRA, London.

FAULKNER, P.M., and WEARY, M. D. (2000): Reducing pain after dehorning in dairy calves. Journal of Dairy Science, 83: 2037-2041.

FRASER D., BROOM, D. B. (1990): Farm animal behaviour and welfare. CAB International, Wallingford, Oxon.

FREGONESI, J.A. (1999): Production and behaviour of dairy cattle in different housing systems. University of London, Ph.D. Thesis.

FREGONESI, J.A., and LEAVER, D. L. (2001): Behaviour, performance and health indicators of welfare for dairy cows housed in strawyard or cubicle systems. Livestock Production Science, 68: 205-216.

GALINDO, F. and BROOM, M. D. (2000): The relationships between social behaviour of dairy cows and the occurrence of lameness in three herds. Research in Veterinary Science, 69: 75-79.

HRISTOV, S. (1996): Koliformni mastitis krava. Vet. glasnik, 50, 5-6, 329-340.

HRISTOV, S. (2002): Zohigijena. Poljoprivredni fakultet, Beograd

HRISTOV, S. (2003): Novi standardi o uslovima gajenja domaćih životinja. Zbornik radova Simpozijuma agroekonomista sa međunarodnim učešćem "Poljoprivreda i ruralni razvoj u evropskim integracijama", Beograd, 461-467.

HRISTOV, S., ANOJČIĆ, B., VUČINIĆ MARIJANA, STANKOVIĆ, B. (1996): Uticaj prašine vazduha na organizam životinja. VII Savetovanje DDDDD, Zbornik radova, 268-275.

HRISTOV, S., BEŠLIN, R. (1991): Stres domaćih životinja. Monografija. Poljoprivredni fakultet. Beograd.

HRISTOV, S., LAZAREVIĆ, N., RADOVANOVIĆ, M., JOŽEF, I. (1998): Stafilokokni mastitis krava. Zbornik naučnih radova XII Savetovanja agronoma, veterinara i tehnologa, Aranđelovac, 4, 1, 411-422. 
HRISTOV, S., LAZAREVIĆ, N., RADOVANOVIĆ, M., PAVLOVIĆ, M. (1997): Streptokokni mastitis krava. Zbornik naučnih radova XI Savetovanja agronoma i tehnologa sa međunarodnim učešćem, Aranđelovac, 3, 1, 415-424.

RISTOV, S., RELIĆ RENATA, (200): Neprijatni mirisi i štetni gasovi u animalnoj proizvodnji. Zbornik radova XII Savetovanje iz dezinfekcije, dezinsekcije i deratizacije u zaštiti životne sredine, sa međunarodnim učešćem. Banja - Junaković Apatin, 197-202.

HRISTOV, S., RELIĆ RENATA, JOKSIMOVIĆ-TODOROVIĆ MIRJANA, DAVIDOVIĆ VESNA, (2006): Mikroklimatski i higijenski uslovi gajenja goveda. Poglavlje u monografiji: Ostojić M. (2006): Zlatarski sir. Institut za ekonomiku poljoprivrede, Beograd, 55-78.

HRISTOV, S., RELIĆ RENATA, STANKOVIĆ, B. (2002) Failures in conveying hygienic procedures during milking of cows. Journal of Agricultural Sciences, Vol. 47, No 2, $233-240$.

HRISTOV, S., STANKOVIĆ, B., JOKSIMOVIĆ TODOROVIĆ MIRJANA, BOJKOVSKI, J., DAVIDOVIĆ VESNA, (2007): Uticaj toplotnog stresa na proizvodnju mlečnih krava. Zbornik naučnih radova, Vol.13 (3-4): 47-54.

HRISTOV, S., STANKOVIĆ, B., RELIĆ RENATA, (2005): Klinički i subklinički mastitis u krava. Biotehnologija u stočarstvu, 21(1-2), 29-39.

HRISTOV, S., TODOROVIĆ MIRJANA, NEŠIĆ KSENIJA, (2000): Najznačajniji aspekti programa sprečavanja pojave i suzbijanja mastitisa krava. Arhiv za poljoprivredne nauke, Vol. 61, $\mathrm{N}^{\mathrm{o}} 211,135-146$.

HRISTOV, S., VUČINIĆ MARIJANA, RELIĆ RENATA, STANKOVIĆ, B. (2006): Uslovi gajenja, dobrobit i ponašanje farmskih životinja. Biotehnologija u stočarstvu, 22, $73-84$.

HUGHES, J. W. (1997): Environmental control of bovine lameness. BCVA, vol 5, part 3: 235-246

LEAVER, J.D. (1999): Dairy cattle. In: Ewbank, R., Kim-Madslien, F., Hart, C.B. (Eds.), Management and Welfare of Farm Animals, 4th Edition. The UFAW Handbook. Universities Federation for Animal Welfare, Wheathampstead, UK, pp. $17-47$.

LOGUE, D. N. (2004): Subclinical mastits and Staphylococcus aureus. SAC Veterinary Services report.

LOGUE, D. N. (2004a): Streptococcus uberis - an update. SAC Veterinary Services report.

LOGUE, D. N. (2004b): Mastitis and Staphylococcus aureus. SAC Veterinary Services report.

LOGUE, D.N., MCNULTY, D. and NOLAN, A. M. (1998) Lameness in the dairy cow: Pain and welfare. The Vet. Journal, 156: 5-6.

RAJKONDAWAR, P.G., NEERCHAL N., VARNER A. M., EREZ B., LEFCOURT M. A., DYER M. R., and TASCH U. (2001): Development of a bovine lameness index that correlates visual lameness scores to measurable limb movement variables--a pilot study. Journal of Animal Science, 79: 16 (Suppl. 1). 
RUSHEN, J. and de PASSILLE, A. M. B. (1998): Behaviour, welfare and productivity of dairy cattle. Can. J. Anim. Sci., 78 (Suppl.): 3-12.

VUČINIĆ MARIJANA, (2006): Ponašanje, dobrobit i zaštita životinja. Fakultet veterinarske medicine, Beograd.

WARD, W. R. (2001): Lameness in dairy cattle. Irish Vet. Journal, 54:129-139

WEBSTER J. (2005): Animal Welfare: Limping Towards Eden. Blackwell Publishing.

WELlS, S. J., OTT, S. L., HILlBERG SEITZINGER, A. (1998): Key health issues for dairy cattle - New and Old. J. Dairy Sci., 81: 3029 - 3035. 